Artículo

\title{
Acceleration, Alienation, and Resonance. Reconstructing Hartmut Rosa's Theory of Modernity
}

Aceleración, alienación y resonancia. Reconstruyendo la teoría de la modernidad de

\section{Hartmut Rosa}

\section{Darío Montero*}

Felipe Torres**

*UNIVERSIDAD DE CHILE

**UNIVERSITÄT ERFURT - MAX WEBER KOLLEG

\begin{abstract}
:
The article presents in an interpretative and critical way the main theses structuring the work of Hartmut Rosa, namely: his theory of modern acceleration; his observations on the types of alienation that arise with it; and the forms of overcoming a state of alienation both within social life and in terms of the relationship nature-humanity, under the concept of resonance. Issues such as modern temporal structures (acceleration), the lack of synchronies between politics and economy, and the obstacles to emancipation (i.e., alienation), as well as the possible ways of confronting modern pathologies (resonance) are key points in Rosa's diagnosis and critique. All of them are grounded on common questions about the origin of modernity, its main features and its later state of development. Two moments in Rosa's trajectory are identified: one closer to a theory of society - in the case of acceleration -, and one approaching a normative philosophy - when dealing with alienation and resonance.
\end{abstract}

Keywords: Acceleration; Alienation; Resonance; Modernity; Critical Theory.

\section{Resumen:}

El artículo expone de manera interpretativa y crítica las principales tesis que estructuran la obra de Hartmut Rosa, y que se resumen en: una teoría de la aceleración moderna; sus observaciones sobre los tipos de alienación surgen que con ella; y las formas de superación 
de una relación alienada tanto en la vida social como en el vínculo naturaleza-humanidad bajo el concepto de resonancia. Temas tales como las estructuras temporales modernas (aceleración), las faltas de sincronía entre política/economía y los obstáculos ante las posibilidades de emancipación (alienación), así como las posibles formas de hacer frente a las patologías modernas (resonancia) serán claves en el diagnóstico y crítica de Rosa. A todos estos temas subyacen preguntas comunes sobre el origen de la modernidad, sus características y su estado actual. Se identifican dos momentos en su obra: un primero, más cercano a una teoría de la sociedad (en el caso de la aceleración), y un segundo momento más próximo a una filosofía normativa (cuando se discute sobre alienación y resonancia).

Palabras clave: Aceleración; Alienación; Resonancia; Modernidad; Teoría crítica.

Recibido: 5 de noviembre de 2019

Aceptado: 23 de diciembre de 2019

\section{Introduction}

Modern society has been one of the major problems addressed by social sciences, but its conceptualization has taken many forms. While some have defined modernity by certain fundamental moral, aesthetic, social and political ideals and commitments, others have limited their endeavors to offer analytic descriptions of the phenomenon. The implications

of these diverse theoretical approaches are evident: in the former case, the description itself carries with it a strong evaluation of what is characteristic for moderns that, in turn, marks a clear standard against which existing social institutions and practices can be critically measured. In the latter, such a positive standard of evaluation does not figure, at least not explicitly. The present article tries to shed light on the differences between these "normative" and "analytic" conceptions of modernity by examining the theory of "social acceleration" elaborated by contemporary German philosopher and sociologist Hartmut Rosa. It is our basic contention that Rosa's critical theory of modern society - one of the most important contributions of the past two decades in Europe - offers both an analytic description of 
modernity and a strong normative reading of the phenomenon; a bifocal approach that is not without difficulties and contradictions.

According to Hartmut Rosa, "modern societies are regulated, coordinated and dominated by a tight and strict temporal regime which is not articulated in ethical terms. Hence, modern subjects can be described as minimally restricted by ethical rules and sanctions, and therefore as 'free', while they are tightly regulated, dominated, and suppressed by a largely invisible, de-politicized, undiscussed, under-theorized and unarticulated time regime. This time-regime can in fact be analyzed under a single, unifying concept: The logic of social acceleration". ${ }^{1}$ This notion is therefore postulated as the essential feature of modernity, while containing no discernible normative content; it refers to something like a "blind" force operating behind the agents' backs. As we will see, a critical social theory should, according to Rosa, unveil the temporal norms secretly governing our lives, but these norms would seem, at least at first sight, to be neutral in moral terms and thus not susceptible of articulation in terms of a conception of the good. One could describe Rosa's theory as belonging to the analytic "camp" among contemporary theories of modernity. In and of itself, acceleration would not have a normative import (pace Goethe, who called "velociferic" the social acceleration tendencies that he witnessed, implying a new type of evil, something immoral and counterproductive for the human spirit who needs time for things to ripen). But Rosa's critical theory of modernity goes beyond this, in two ways. First, behind the logic of acceleration there also exists a conception of the good life, which is inextricably linked to the enlightened narrative of reason and progress: the promise of a steady amelioration in the quality of people's lives based on scientific and technological advancements, which in turn allows for an appropriation of the world in making the world available, attainable, and accessible for them. ${ }^{2}$ The secular impetus towards the multiplication of the number of experiences per unit of time (in place of the religious promise of an eternal after-life), the enlightened promise of progress and the modern complex of motivations - "the triple A approach to the good life", in Rosa's terminology - contribute, now from a cultural point of view, to making a more comprehensive and plausible diagnosis of modern society. But

\footnotetext{
${ }^{1}$ Hartmut Rosa, Alienation and Acceleration. Towards a Critical Theory of Late-Modern Temporality (Malmö: NSU Press, 2010), 8.

${ }^{2}$ Klaus Dörre, Stephan Lessenich and Hartmut Rosa, "Appropriation, Activation and Acceleration: The Escalatory Logics of Capitalist Modernity and the Crises of Dynamic Stabilization”, Theory, Culture \& Society 34, no. 1 (2017): 53-73.
} 
secondly, Rosa's concept of resonance, while clearly pointing to a human good (as the answer to the question, What is a non-alienated life?) seems to transcend the cultural specificity of Western modernity, as if it were an invariant feature of the human condition. The fruitfulness of Rosa's project triggers several questions, that we will try to address as the argument unfolds. Among these: Does the notion of social acceleration reveal an implicit normative content when identified as bringing "totalitarian" tendencies and claimed to lead to human alienation and suffering? Can we really speak of an invariable human nature, or is the value of resonance only intelligible within the modern culture and mindset? Taken as a whole, Is this a "cultural" or "a-cultural" theory of modernity - or a mix of both?"

To gain a better understanding of Rosa's critical theory of modernity, in this article we propose to split the author's work in two main phases. There is an early period - roughly the decade from 1999 to 2009 - in which he elaborates his theory of social acceleration of modern society, in which the priority is given to structuralist and functionalist explanations (i.e., de-synchronization between social spheres), to the usage of analytic or merely descriptive conceptual categories (social acceleration), and in which dominates a relatively acultural, neutral, universalist language - recalling one of Weber's rationalization theses as an impersonal, unavoidable, and global impulse. The critical yields of Rosa's theory of acceleration will be examined, while presenting this approach. In the later period (20092019), the question of (dys)functioning of social systems is replaced by the question of the just social order and the good life under (late) modern conditions, put in terms of self-world relations. Following Axel Honneth, Rosa commits himself to an immanent critical theory, which seeks the grounding of social critique on a reconstruction of the experiences and conceptions of good life espoused by the social actors under study. With respect to this normative-immanent-critical project, however, we think it is possible to recognize an ambiguity in Rosa's position between a more contextual claim - reminiscent of communitarian thinkers like Michael Walzer - and a more universalist one - as expounded in his comprehensive book on 'resonance', a universal human desire or longing, something like an anthropological invariant. The last part of this article will be devoted to both evaluating recent criticisms to Rosa's theory and reflecting along the lines of continuity and discontinuity, which are visible in this work considered as a whole.

\footnotetext{
${ }^{3}$ Charles Taylor, "Two Theories of Modernity", Hastings Center Report 25 (1995): 24-33.
} 
Though quite a lot of his work is available in English, Rosa is still much less wellknown in the English-speaking world than he is in Germany. In his first major work, Beschleunigung. Die Veränderung der Zeitstrukturen in der Moderne, ${ }^{4}$ he convincingly sets out a wide-ranging theory of social acceleration and its consequences. The "solutions" to the problems diagnosed there have been addressed in his more recent book, Resonanz. Eine Soziologie der Weltbeziehung, recently appeared also in English by Polity Press. ${ }^{5}$ Even less promising looks the panorama in the Spanish-speaking world where, with the exception of one relevant article ${ }^{6}$ appeared in the Chilean journal Persona y Sociedad in 2011 and the book Alienación y Aceleración by Katz in 2016; just recently, the Spanish translation of Resonance has recently appeared, while the book on social acceleration will finally be available in Spanish during 2020. ${ }^{7}$ With this in mind, this brief article has a twofold mission: on the one hand, to settle this pending account by discussing Rosa's work and its impact beyond the German-speaking world and, on the other hand, to offer a line of interpretative and critical reading of his main arguments.

\section{A Critical Sociology of Temporal Patterns}

Hartmut Rosa's interest in the phenomenon of acceleration can be traced back to his early writings about the modernization process, where he pointed out the relevance of temporal structures for an adequate comprehension of modernity. ${ }^{8}$ The observation of incessant movement and massive changes in the social structures of Western Societies in the past

\footnotetext{
${ }^{4}$ Hartmut Rosa, Beschleunigung. Die Veränderung der Zeitstrukturen in der Moderne (Frankfurt: Suhrkamp, 2005); Social Acceleration. A New Theory of Modernity, Jonathan Trejo-Mathys trans. (New York: Columbia University Press, 2013).

${ }^{5}$ Hartmut Rosa, Resonanz eine Soziologie der Weltbeziehung (Berlin: Suhrkamp, 2016); Resonance: a Sociology of Our Relationship to the World, James C. Wagner trans. (Cambridge UK: Polity Press, 2019).

${ }^{6}$ Hartmut Rosa, "Social Acceleration: Ethical and Political Consequences of a Desynchronized High-Speed Society", Constellations 10, no. 1 (2003): 3-33.

${ }^{7}$ Hartmut Rosa, "Aceleración social: consecuencias éticas y políticas de una sociedad de alta velocidad desincronizada", Persona y Sociedad XXV, no. 1 (2011): 9-19; Alienación y aceleración: Hacia una teoría crítica de la temporalidad en la modernidad tardía (Buenos Aires: Katz ediciones, 2016); Resonancia: Una sociología de la relación con el mundo, Alexis Gros trans. (Buenos Aires: Katz ediciones, 2019); Aceleración. La transformación de las estructuras temporales en la Modernidad, Felipe Torres trans. (Mexico City: Herder, forthcoming).

${ }^{8}$ See Hartmut Rosa, "Jedes Ding hat keine Zeit? Flexible Menschen in rasenden Verhältnissen”, in Zeitgewinn und Selbstverlust: Folgen und Grenzen der Beschleunigung, Vera King and Benigna Gerisch eds. (Frankfurt: Campus, 2009), 21-39.
} 
centuries led Rosa to the development of a theory of social acceleration. During the late 1990s and early 2000 s, several texts concern with time, movement, speed, or directly acceleration. ${ }^{9}$ Together they constitute a long-term reflection upon temporal phenomena in late-capitalist societies, with an ever-increasing global reach. Notwithstanding, his more celebrated work on temporal structures is undoubtedly his opus magnum - the already mentioned Beschleunigung, translated in the English version as Social Acceleration. A New Theory of Modernity. In that book, Rosa gathers all his reflections on the temporal structures of modern societies and develops them in extenso. This remarkable effort constitutes a major contribution to a theory of acceleration in particular, and to social theory in general.

Broadly speaking, we identify in these group of writings two complementary goals: on the one hand, Rosa seeks to demonstrate that modernity is from the very beginning a project that involves temporal patterns; on the other hand, he suggests more specifically that the temporal project underlying modernity can be understood in terms of increasing rates of change (cultural, economic, and technological), which altogether constitute a historical process of acceleration. But, Where can we recognize the critical bent of this theory? In a recent interview, Rosa states that what he is taking from Critical Theory is, first of all, the interest in changing social conditions, and he declares to be in the same orbit of Adorno's and Marcuse's theories of modernity. ${ }^{10}$ Then, which kind of theory of modernity is it? And what kind of critical theory does it represent? At first sight it is notorious that Rosa's theory of acceleration follows the same path of traditional Critical Theory in that it exposes a structural condition of current society by reconstructing its historical becoming. Some of Rosa's references for describing the new times are the modern claim for rupture with the past in terms of an invigorated role of human agency in history; ${ }^{11}$ the scission between space of

\footnotetext{
9 Among them, we can count: "Bewegung und Beharrung. Überlegungen zu einer sozialen Theorie der Beschleunigung", Leviathan 27, no. 3 (1999): 386-414; "Social Acceleration: Ethical and Political Consequences"; "The Speed of Global Flows and the Pace of Democratic Politics", New Political Science 27 (2005): 445-59; “Jedes Ding hat keine Zeit?”, and the already mentioned book Alienation and Acceleration.

${ }^{10}$ Darío Montero, “Theories of Modernity. Interview with Hartmut Rosa” (Part 2, min: 10'55). Centro para las Humanidades UDP, Santiago de Chile, 2018, accessed August 2019, available at https:/www.centroparalashumanidadesudp.cl/1393-2/. This interview was published as Darío Montero, "La modernidad acelerada y sus desafíos. Una conversación con Hartmut Rosa", Revista de Humanidades 41 (2020): 281-307.

${ }^{11}$ For a short overview on this, see Felipe Torres, "Tiempo Histórico. Una promesa de aceleración”, Isegoría 59 (2018): 553-71.
} 
experience [Erfahrungsraum] and the horizon of expectation [Erwartungshorizont], ${ }^{12}$ and the ensuing lifetime and universal time distinction described by Hans Blumenberg, ${ }^{13}$ as well as theories upon the compression of the present (Harvey, Lübbe). ${ }^{14}$ All of them configurate an specific historical condition with possibilities and risks. The modern conjunction between acceleration and alienation is not, however, a dead-end situation. In line with the tradition of critical theory of the Frankfurt School, Rosa is dedicated not only to diagnosing the problems of our time, but also to identify their emancipatory potentials. In the same vein, Rosa's analysis seeks to pinpoint the principal features of contemporary societies that are pointed out in the three accelerator motors (economical, cultural, technical) and the "dynamic stabilization". To complete the critical project, he also offers a pivotal evaluation of the pathological consequences of a high-speed society.

Furthermore, it is possible to identify three major influences on Rosa's theory of acceleration, beginning with the classical "rationalization" thesis. Even though Max Weber did not develop an accurate theory of acceleration, the rationalization-process of society described in his well-known works on the "capitalist ethics" and Economy and Society are the starting-points for an increasingly high-speed society. The historical rationalization process, which affected Europe during the eighteenth and nineteenth centuries, ended at the creation of a cultural mindset for instrumental control and maximization of almost every social aspect. Thus, the technological improvements and the development of a bureaucratic apparatus can be understood under the light of the rationalization process described by Max Weber. ${ }^{15}$ The rule of efficiency and control over nature and social phenomena achieving the

\footnotetext{
${ }^{12}$ This term was coined by the German historian Reinhart Koselleck. For the concepts of "space of experience" and "horizon of expectation", and their gradual divergence in modern times, see Reinhart Koselleck, Vergangene Zukunft. Zur Semantik geschichtlicher Zeiten (Frankfurt: Suhrkamp, 2000), 349. There is English version: Futures Past. On the semantics of Historical Times, Keith Tribe trans. (New York: Columbia University Press, 2004).

${ }^{13}$ According to Hans Blumenberg, the modern era is a time in which there is non-identity possible between the lifetime and the cosmic time since the individual cannot perceive her life as synchronized with the time of the history. See Hans Blumenberg, Lebenszeit und Weltzeit (Frankfurt: Suhrkamp, 1986).

${ }^{14}$ David Harvey, The Condition of Postmodernity: An Enquiry into the Origins of Cultural Change (Cambridge UK: Blackwell, 1990); Hermann Lübbe, "The Contraction of the Present", in High-speed society: social acceleration, power, and modernity, Hartmut Rosa and William Scheuerman eds. (University Park: Pennsylvania State University, 2009), 159-78.

${ }^{15}$ Max Weber, Wirtschaft und Gesellschaft (Tubingen: Mohr, [1921] 1976). English version: Economy and Society (New York: Bedminister, 1968). For a complementary overview, see Karl Löwith, "Weber's Interpretations of the Bourgeois-Capitalistic World in Terms of the Guiding Principle of 'Rationalization'", in Max Weber, Dennis Wrong ed. (Englewood Cliffs NJ: Prentice-Hall, 1970), 101-22.
} 
maximum results with a minimum effort preludes a high-speed social development, since within a rational mode of production "there is no time to lose". Organizing huge amounts of data under bureaucratic schemes or rationalizing the production series are ways for getting optimal results in less time. Due to the introduction of rational thinking for settling temporal phenomena such as measurable and calculable time and, in turn, reducing the time through rationalized transportation and communication's systems, the resulting coordination promoted a high-speed society. By standardizing the social spheres via rational squeezes, an accelerated process was facilitated and encompassed. Broadly speaking, this rational acceleration is also the result of a new secular mindset. From the emergency of historical times and of an historical consciousness related to the loss of religious influence, the human efforts were considered as a core-condition for fate within history. ${ }^{16}$ Then, a secular projection towards future that goes hand-in-hand with ideas of progress, utopias, and revolutions started to promote a new historical pace. Finally, the human effort focused upon the bond that supposes to be fast and to be more powerful promoted a global history. ${ }^{17}$ In the following, we will address in more detail Rosa's diagnosis of acceleration as well as his considerations about its possible temporal pathologies.

\section{Frenetic Standstill. An Irrational Becoming of Rationalization}

As result of processes such as rationalization and secularization (Weber), individualization (Simmel), differentiation (Durkheim) and domestication or commodification of nature (Marx), modernity is configured by the problematic interconnection of three types of acceleration: technological, economic, and of the rhythm of life. Meanwhile, at the structural level these processes gave rise to what Rosa called 'dynamic stabilization' - the condition that the modern social order can only be maintained through the logic of incessant growth and escalation -, they also result, for individuals, in the alienating experience of a "frenetic

\footnotetext{
${ }^{16}$ For a more detailed analysis upon the connection between acceleration and secularization, see Felipe Torres. "A secular Acceleration. Theological foundations of the sociological concept 'Social Acceleration", Time \& Society 25, no. 3 (2016): 429-49.

${ }^{17}$ It is not possible to be extensive on this. It would suffice it to say that, for Paul Virilio, to be faster is also a manifestation of power that is clearly seen in colonizing expeditions: hence whoever colonizes not only has a weapon but also speed or, more precisely, uses speed as a weapon. See Paul Virilio, Speed and Politics: An Essay on Dromology (New York: Semiotext(e), 1986).
} 
standstill" (rasender Stillstand): the feeling that one must continue advancing and striving harder, at an ever faster rate, and preferably faster than others, without feeling that one is really going anywhere. Thus, one of the crucial aspects of the critical renderings from the theory of acceleration is the constant movement of social process and the increasing rate of changes without meaning that radical transformations imply. To put it briefly, to have more dynamism in social structures does not mean that there are structural transformations taking place. Even when modern times supposes a structural transformation of the temporal patterns. In fact, late capitalist societies are basically in a paralysis-in-movement. Following Paul Virilio's polar inertia, Rosa named this situation as frenetic standstill or stagnation.

To take an example from a specific field of society in which the temporal phenomena can be grasped, we will overview the case of politics, since it involves almost every other social aspect. Although progressive politics are usually oriented towards changing things and, in that sense, are more related to acceleration, the political character of current acceleration is an open question. Economical "free" market and political tendencies in late capitalism that support neoliberal economy can be strongly related to accelerations, but not necessarily in a progressive-leftist manner. Consolidating innovations does not mean necessarily a deep change in economic structures or societal stratifications. In fact, Rosa himself speaks about the "frenetic standstill" as constitutive diagnosis of the epoch. ${ }^{18}$ Frenetic standstill therefore means that nothing remains the way it is, while at the same time nothing essential changes. ${ }^{19}$ Then, the static movement is the result of claims for controlling social process through rational mechanisms. But instead of getting more improvements, the actual outcome is the speed-up inertia that does not pursue "rational" purposes. Following a type of argument which recalls Horkheimer and Adorno's criticism in the Dialectic of Enlightenment ${ }^{20}$ - being enlightenment originally a promise of emancipation that ends up with the human domination of nature and human by rational means -, the frenetic standstill

\footnotetext{
18 "The two diagnoses of the time that appear so contradictory, social acceleration and societal rigidity, are only at first glance contrary to one another. In the memorable metaphor of a "frenetic standstill" (rasender Stillstand), which we owe to an inspired translation of Paul Virilio's inertie polaire, they are synthesized into a posthistoire diagnosis in which the rush of historical events only provides scant cover for (and ultimately, in effect, produces) a standstill in the development of ideas and deep social structures." Rosa, Social Acceleration ..., 15. In that quotation Rosa refers to the German translation of Virilio's L'Inertie Polaire, namely Rasender Stillstand. Essay (Munich: Hanser, 1992).

${ }^{19}$ Rosa, Social Acceleration, 283. Italicized in the original.

20 Theodor Adorno and Max Horkheimer, Dialectic of Enlightenment (Stanford: Stanford University Press, 2002).
} 
is the counter-face of the modern promise of improvements via increasing the pace of social process aimed at reaching better life conditions. This is the case in the development of liberal democracy. Its first move was the expansion of formal liberties and equal claims, whereas in a second moment -i.e., late capitalism - it is faced with a paralyzing process of social change. While in the first moment social and individual rights are gained, in a second moment these mutate into another type of alienation. Invoking the idea of frenetic standstill (wherein "nothing remains the way it is while at the same time nothing essentially changes" ${ }^{21}$ ), Rosa argues that we are currently speeding into a post-historical void, with no path or direction. The argument is not entirely unlike that of the already mentioned Horkheimer and Adorno's, but also Herbert Marcuse's in One Dimensional Man, ${ }^{22}$ in which dialectics have been replaced by the one-dimensionality of technical progress (both in the United States and the Soviet Union) and cultural industry (mostly in Western societies). According to Rosa,

The temporal scope of the consequences of political decisions plays a central role for the functional capacity and legitimation of democratic systems of the Western type: if political decisions have serious, long-term, irreversible consequences, then, to the extent that the legitimacy of decisions in the eyes of a minority disappears, the general basis for democratic decisions seems to become questionable. ${ }^{23}$

In this regard, it is not the main issue if we are before a reactionary, democratic or revolutionary political perspective; all of them would be situated respectively in a temporal specificity, "[t]hus progressive and conservative often designate different speeds rather than genuinely different directions: according to its own self-understanding, progressive politics strives toward an acceleration of the expected development of history, conservative politics toward its deceleration or temporary suspension". ${ }^{24}$ Therefore, the paradox for politics is that, one the one hand, there is a shortening of time horizon which turns into scarcity of time resources, and on the other it exists a widening of time horizon that increase the need for time. This means that socio-political decision-making demands fast solutions in parallel with

\footnotetext{
${ }^{21}$ Rosa, Social Acceleration, 283.

${ }^{22}$ Herbert Marcuse, One-Dimensional Man (London: Routledge, 2006).

${ }^{23}$ Rosa, Social Acceleration, 253.

${ }^{24}$ Ibid., 258.
} 
needing enough time for considering, processing, and developing the best choices. This can be described also in terms of paradoxical patterns, which tend to either homogenize or heterogenize time experience at once. The process of acceleration that Rosa describes extensively is here understood in a complementary way, as a temporal regime that homogenize practices and expectations. Usually, in this hegemonic pace there is no place for doubts or delays. This cultural dominance stabilizes a regime of high-speed that puts under pressure other rhythms in order to follow it. But it does not mean that can absorb the whole diversity of rhythms; instead, it creates conditions for the rest of paces to emulate its temporal regime. According to Rosa,

the speed-up of society at first enabled, supported and encouraged democratization, but then, beyond a certain critical threshold, the reverse effect occurs: the speed of social change and the dynamics of socioeconomic, cultural and technological development threaten to undermine the proper functioning of democracy. Thus, it is my claim that democracy only works properly within a certain time - or "speed-frame" of social change. ${ }^{25}$

Before continuing our reconstruction of Hartmut Rosa's critical theory of modernity, it is important to make explicit the general character of this first period in his intellectual biography. During the decade 1999-2009, roughly speaking, Rosa openly advocates a functionalist critique of social acceleration as a force which threatens to destroy the feasibility of system(s): modern society's capacity to reproduce (materially/symbolically) itself in the long-run based on a diagnosis of systemic malfunctions or dysfunctionalities. In this type of social critique, he asserts pragmatically that a societal formation would not work in the long run, like Marx did when he exposed the internal contradictions of capitalism leading necessarily to cyclical economic crises. What Rosa does is to show a series of desynchronizations among social spheres caused by social acceleration such as the timing for political decision-making in contexts of economic and technological rush. But it is clear that, at least from this (functionalist-structuralist) standpoint, there is no need in finding a

\footnotetext{
${ }^{25}$ Hartmut Rosa, "The Speed of Global Flows", 446.
} 
substantive normative yardstick for evaluating actual social institutions and practices. This is precisely what he attempts to find later.

\section{A Sociology of the "Good Life": From Acceleration to}

\section{Alienation}

The second period in Hartmut Rosa's intellectual biography seems to begin with his 2009 collaborative volume along with his Jena colleagues Klaus Dörre and Stephan Lessenich, where Rosa states bluntly that sociology's ultimate object and preoccupation is the question about good life, that is to say, "an analysis of the social conditions under which a fulfilled life becomes possible." ${ }^{26}$ According to Rosa, all the classical sociological thinkers - from Marx to Weber through Durkheim and Simmel - began their reflections from a somehow conscious sense that something was going wrong in the path of the society as a consequence of powerful ongoing modernization processes such as industrialization, urbanization or rationalization; that behind the wonders of the modern world, its subjects were experiencing alienation, exploitation of nature, or loss of freedom and meaning. In this sense, sociology possessed right from the start a critical bent (though later positivistic and science-oriented approaches to sociology attempted to formulate more neutral goals for the discipline). This critical stance towards modernity with an eye on the question of the good life builds the premise of Rosa's thinking in this second phase of his intellectual biography. From this moment on, the influence of Charles Taylor and contemporary communitarian philosophy becomes more apparent in his writings. Where does the social critic obtain the standards for carrying on his or her task? Not from the philosophical elucidation of rational universalistic norms, nor from theological insights on the good life, but from society itself. Moreover, Rosa now advises to move away from a critique of modern capitalism based on "inherent economic contradiction and functional problems," and to grasp its "ethical root". ${ }^{27}$

\footnotetext{
${ }^{26}$ Hartmut Rosa, "Kapitalismus als Dynamisierungsspirale - Soziologie als Gesellschaftskritik", in Soziologie - Kapitalismus - Kritik, K. Dörre, S. Lessenich, and H. Rosa eds. (Frankfurt: Suhrkamp, 2009), 87. Authors' translation here and in the citations from German editions which follow - unless indicated otherwise.

${ }^{27}$ Rosa, "Kapitalismus als Dynamisierungsspirale", 125.
} 
It is in his 2010 essay entitled Alienation and Acceleration: Towards a Critical Theory of Late Modern Temporality where Rosa develops the abovementioned intuitions in a more comprehensive way. He claims that social acceleration may be relevant for an analysis of the normative conditions of modern life, that is to say, for gaining a better understanding of the sufferings and realizations of our contemporaries, as well as for fruitfully reflecting on the principles of a just society. And he does this in two ways. First, by observing that "the silent normative force of temporal norms" 28 evidently puts pressure on the lives of modern subjects, and secondly, by assuming the stronger thesis that the acceleration regime influences the whole way we humans relate to the world that surrounds us, usually making our relationships problematic. ${ }^{29}$ At first sight, the new experiences of time and space, and the novel forms of self-understanding and interaction that our accelerated society brings along, cannot be said to be good or bad, but on a closer look these massive changes do possess the potential for creating human suffering in multiple ways. This confirmation opens the door for the elaboration of Rosa's own version of a critical theory, following the steps of the Frankfurt School tradition. How does he position himself within this tradition?

While owning greatly to the main figures of Critical Theory, Rosa's position is founded on an intellectual independence that affords to avoid the temptation of classifying him as belonging to the "fourth" generation of the School. In any case, the most palpable influence should be attributed to Rosa's mentor and colleague, Axel Honneth. According to the latter, the starting point of a contemporary Critical Theory and of social philosophy in general should be the identification of social pathologies, and this entails the actual experiences of social actors. This phenomenological grounding on real experience and suffering aims at avoiding the recourse to a metaphysical determination of a human nature outside of history, which for Rosa has no room in our times. The other major influence of Rosa's thinking comes, as we mentioned, from the Canadian philosopher Charles Taylor, who argues that human beings always possess a sense of what is good - no matter how unconscious this sense is -, which helps us to orient ourselves through life. With these two principles in hand, Rosa claims that, "the most promising route for a contemporary version

\footnotetext{
${ }^{28}$ Rosa, Alienation and Acceleration, 41-2.

${ }^{29}$ Hartmut Rosa Weltbeziehungen im Zeitalter der Beschleunigung. Umrisse einer neuen Gesellschaftskritik (Berlin: Suhrkamp, 2012), 374-413.
} 
of Critical Theory lies in a critical test of social practices in the light of the conceptions of the good life held by social actors themselves." 30

Such a post-metaphysical program implies the reconstruction of the normative standards of critique from historical and culturally specific sources. Since the values of freedom, autonomy, authenticity, and the like, are inextricably linked to Western-modern societies, any critique of institutions and practices should therefore be based on, and measured against, those aspirations and conceptions of the good. The people who suffer are the ones who know (though perhaps implicitly) what is the goal or state to achieve, and that is why social institutions can only be maintained in the long run if they enjoy a certain degree of legitimacy in the eyes of normal people. Rosa's retrieval of common people's selfunderstandings in a way follows Jürgen Habermas anti-paternalistic position, which he developed in critical dialogue with the first generation of the Frankfurt School, particularly with respect to the late Theodor W. Adorno. ${ }^{31}$ Building on these theoretical basis, Rosa concludes that, "social acceleration has become a totalitarian force in and of modern society, and hence that it should be criticized like all forms of totalitarian rule...in late-modern society, the totalitarian power rests in an abstract principle that nevertheless subjects all who live under its rule." 32 The temporal urge to accelerate is hardly perceived as a social construct and almost impossible to fight back, but, Who's the one to blame?

While it is undeniable that modern individuals enjoy a greater degree of freedom than in the past (at least formally), it is also true that there is mounting evidence going in the opposite direction. Especially in late modernity, people feel overwhelmed by an immense array of pressures and demands and the generalized sensation that we have to run faster and faster just to keep job, status, and probably also couple - a state of affairs that, in Rosa's opinion, follows from the competitively driven acceleration game, from the most general social patterns down to individuals' everyday lives. Highly demanding temporal norms take the place of older, religious, or traditional rules. We live under tight schedules, deadlines, and the requirement of express delivery and instant gratification. Ironically, religious-like feelings of guilt reappear in contemporary times due to the people's inability to fulfill these

\footnotetext{
${ }^{30}$ Rosa, Alienation and Acceleration, 52.

${ }^{31}$ Axel Honneth, The Critique of Power. Reflective Stages in a Critical Social Theory (Cambridge MA: The MIT Press. 1991), Part II.

${ }^{32}$ Rosa, Alienation and Acceleration, 61.
} 
contradictory demands. Temporal norms acquire a totalitarian character, very different from what past societies experienced. "Even though they clearly are socially constructed, they do not actually come in an ethical guise, not even as political norms, but as brute facts, as laws of nature which cannot be disputed or discussed. Temporal norms simply appear to be 'out there', and it is up to individuals to fulfill them or not. Thus, there is no moral or political debate about the powers of the deadline and the dictates of speed at all". ${ }^{33}$ This "silent" or "hidden" set of rules, which cannot be debated or contested through conscious, rational initiatives, must be the mark or object of a critical theory committed to the main ideals and self-understandings of modernity and which can be synthetized in the promise of reflexive autonomy.

The modern ideal of autonomy, understood by Rosa as individual self-determination in the context of a Western society which aspires to democratic self-rule (political autonomy), on the one hand, and the control of natural forces and substances (techno-economic mastery of nature), on the other, has been reinforced from the beginning by the dynamism unleashed by the processes of social acceleration and competition: economic growth, technical innovation and the meritocratic struggles for status. But this would be no longer the case in late modern societies. Quite the contrary: people in Western societies feel that their autonomy and their freedom are seriously compromised by the unstoppable escalatory logic of the past half century. Rosa's diagnosis finds echoes in the writings of Kenneth Gergen, Richard Sennett, and much postructuralist and so-called postmodern literature of our day. At the most, people seek to adapt themselves to the increasingly competitive economy, but the real possibility of a true liberation - the kernel of the modern-enlightened project - seems hard to believe. And this would lead to alienation, which Rosa preliminarily defines as that state whereby, "we 'voluntarily' do what we do not really want to do." 34 The prolonged history of the notion, stretching back to Rousseau, Hegel and Marx, and continued by the first generation of critical theorists, suffered an interruption in the works of Habermas and Honneth. The re-introduction of the concept of alienation into contemporary Critical Theory, even though the concept was still fuzzy and underdeveloped by 2010 (as the author himself acknowledges), is one of the distinctive features of Rosa's position. But this position must

\footnotetext{
${ }^{33}$ Ibid., 77.

${ }^{34}$ Ibid., 83.
} 
be understood in post-metaphysical terms, in the sense of avoiding any essentialist definition of what might constitute a non-alienated life based on a supposed human nature. Rather, what we fail to achieve when alienated is the possibility of appropriating the world in a meaningful manner. How to make sense of this?

\section{A Sociology of "World Relations": from Alienation to Resonance}

Drawing on a relational ontology, Rosa tries to illuminate the very idea of social alienation in terms of self-world relations, that is, in the (impoverished, distorted) way we humans are placed in the world and relate to our special surroundings, the things we produce and consume, our decisions and actions. What Rosa means by alienation might be more easily grasped as the experience of inability of really and meaningfully appropriating life, leading in many cases to psychological pathologies such as burnout and depression: I may have a good job but I feel strange at the workplace, I may visit beautiful places but the places remain alien to me, I may read an interesting book, and yet the reading turns into a flat, grey experience, of which I will probably remember little afterwards. Even the quality of our social interactions becomes flattened by the prevailing high-speed tempo constraints. The starting point of Rosa's social critique must be the reported experiences of ordinary individuals living their lives, and not the a priori intuitions of the social critic. ${ }^{35}$ Alienation and Acceleration closes with the following statement: "Alienation from the world and alienation from the self are not two separate things but just the two sides of the same coin. It persists when the 'axes of resonance' between self and world turn silent." ${ }^{36}$ From this point onwards, Rosa starts using the idea of resonance (with its acoustic and musical undertones) trying to paint the contours of a fully realized life, where the world "speaks" again and is not silent anymore, where a "responsive" mutual relationship between the human self and the

\footnotetext{
${ }^{35}$ It is worth noticing here that Rosa has taken seriously the "mindfulness", "post-growth" and "Buen Vivir" movements as concrete attempts at offering alternative ways of being-in-the-world that the default one produced by the logic of dynamic stabilization. Cf. Darío Montero, "Aceleración, alienación y resonancia. Entrevista con Hartmut Rosa", in Investigación y teoría crítica para la sociedad actual, M. Basaure and D. Montero eds. (Barcelona: Editorial Anthropos, 2018), 58.

${ }^{36}$ Rosa, Alienation and Acceleration, 97.
} 
world becomes possible. ${ }^{37}$ This is the starting point for his elaboration of a sociology of a good life, which makes use of the idea of resonance and its guiding principle. ${ }^{38}$

This project is further elaborated in Rosa's next book, Weltbeziehungen in Zeitalter der Beschleunigung, where he explains that the task of a sociology of the good life "does not consist in determining the goals, values and content of a realized life (...) but in identifying its social prerequisites and conditions." ${ }^{39}$ For him the question of the good life can be reframed as a question about world relations [Weltverhältnisse, Weltbeziehungen], which are, "always socially, culturally and historically mediated." ${ }^{40}$ These world relations have to be understood as the manner in which human beings connect to the world, their attitudes towards it, how they experience it, but also in how they actively intervene in it, without ever losing sight of the concrete sociological, empirical conditions that mediate these relations. Rosa puts forward the hypothesis that there exists, "a categorical difference between a form of beingin-the-world by which the world (...) appears to the subject as an answering, supporting, breathing 'resonance system', and a world relation which makes the world appear as mute, cold and indifferent - even hostile". ${ }^{41}$ Rosa identifies the latter state as one of alienation. Some contemporary critical theorists, such as Rahel Jaeggi, have embraced the notion of alienation but in order to oppose it to the more formal concept of autonomy. ${ }^{42}$ But this seems to Rosa a false opposition based on the observation that the reduction of obstacles and limits to human autonomy, particularly during the past decades, have led to new and stronger forms of alienation. What could then be the opposite of this state of human alienation? Not authenticity nor autonomy; not even a fully recognized and valued life [Anerkennung], but the idea of resonance.

Recognition may be posited as a necessary but insufficient condition for achieving resonance: the latter only takes place through a dialogue, real or metaphorically speaking. What we mean by metaphorically is that resonance can occur between two human beings but

\footnotetext{
${ }^{37}$ Ibidem.

${ }^{38}$ Notwithstanding Rosa explicit reference to Taylor when speaking of the "axes of resonance", the former claims he did not take the notion from the latter. See Montero, "Aceleración, alienación y resonancia"; also, Hartmut Rosa, "Is There Anybody out There? Stumme und resonante Weltbeziehungen -Charles Taylors monomanischer Analysefokus", in Unerfüllte Moderne? Neue Perspektiven auf das Werk von Charles Taylor, M. Kühnlein and M. Lutz-Bachmann eds. (Berlin: Suhrkamp, 2011), 15-43.

${ }^{39}$ Hartmut Rosa, Weltbeziehungen, 7.

${ }^{40}$ Ibidem.

${ }^{41}$ Rosa, Weltbeziehungen, 8.

${ }^{42}$ Rahel Jaeggi, Entfremdung. Zur Aktualität eines Sozialphilosophischen Problems (Frankfurt: Campus, 2005).
} 
also between a person and a non-human entity. Rosa also catalogues aesthetic and religious types of experience as resonance experiences, as when we connect with a piece of music or we enter with a devotional sentiment in dialogue with higher powers. This seems enough to reason make a clear distinction between (social) recognition and resonance. But the latter is also more difficult to produce - it is impossible to control or induce at will indeed. And since modern society, at least in its dominant current mode of being, is based on an instrumental, strategic rationality, then the structural and cultural condition for resonance relations are far from optimal, offering thus a rather bleak prospect for a fully-realized human life. Rosa sets himself to the task of exploring and reconstructing the concrete, practical conditions under which different types of world relations occur - economic, political and cultural institutions, life forms and habitus. His 2016 impressive work on resonance finally provides a systematic study on the matter. ${ }^{43}$ But, What sort of human desire corresponds with this search for resonance with the world? What can we make of this fundamental concept of this new (critical) social philosophy?

Let us first examine some key sections of the book. Rosa begins by observing the form or the quality of the connection we human establish with others or with our work when we love, and describes it as a "vibrant thread" [vibrierender Draht], which allows us to reach out to the world but also to be moved by it. ${ }^{44}$ Later on, Rosa would argue in the following terms: "Perhaps we can recognize here the rudiments of an alternative action theory, for which the search for resonance and the fear of alienation - not as subjective, emotional state, but as relational modus - build the central driving sources of human agency." 45 When it comes to defining the concept, Rosa starts by examining the physical acoustic phenomenon of resonance [re-sonare] and then proceeds to work it out as a social-scientific category, both with descriptive and normative intent. In his own words: "Resonance is to be understood, first of all, as a basic human need and as a basic human capacity."46 The language Rosa is using here in speaking of a "vibrant thread" of love, of "central driving sources of human agency", or when he refers to resonance as a "basic human need", seems to suggest an important turn in his thinking from his former Western-contextualist stance towards a

\footnotetext{
${ }^{43}$ Hartmut Rosa, Resonanz.

${ }^{44}$ Ibid., 24-5.

${ }^{45}$ Ibid., 198-99.

${ }^{46}$ Ibid., 293
} 
universalist position. How to accommodate Rosa's defense of a universal, a-historical human constant (resonance) with his situated critical analysis of modern, Western societies?

Rosa's acceleration thesis permits to speak of a systematic transformation in the time structures behind the multiples modernities we see in Europe, South America, or Asia. It is a unitary tendency. The escalatory logic means that social, political, economic, and cultural institutions can only reproduce and stay alive if and only if they constantly grow, accelerate, and innovate. On the other hand, Rosa presupposes a generalized desire in the world towards making the world available, accessible, and attainable in all sorts of ways. Therefore, his latest definition of modern society runs as follows: "The social formation of modernity is structurally characterized by its ability to stabilize only in a dynamic way, whereas its cultural program aims at a systematic expansion of an individual and cultural reach of the world."47 This evidently implies a global, universalistic take on modernity, which may orient the efforts for a critique of resonance relations [kritik der resonanzverhältnisse], in that it unveils how social acceleration distorts our position and relation to the world in which we live in, but which has little to say concerning idiosyncratic local, regional or national self-understandings and practices. Arguably, the categories of resonance, alienation and acceleration - and along with these, his whole exegesis of modernity - cannot account for the qualitatively different perceptions, experiences, and sufferings of people in Russia, India, Germany or Chile, not to mention of the inhabitants of smaller localities embedded in particular traditions and habits.

If this is so, then, Rosa's normative critical theory ends up moving away from the contextualist position that he had espoused, for instance in his 2012 book on world relations, where he identifies "four levels (or loci) of self-interpretations" 48 for reconstructing the particular forms people think, act and live together. However, nothing in Rosa's texts prevents one from integrating this sort of analysis into his more universalistic scheme. At the end of the day, what the author is offering is a formal approach to the question of the good life, in order to orient critique. Human beings would strive for resonance, and the social critic should know this is a universal human good, but in what should consist the good life in a substantive sense: that it cannot be anticipated by the critical sociologist, let alone impose it

\footnotetext{
${ }^{47}$ Ibid., 518.

${ }^{48}$ Hartmut Rosa, "Four levels of self-interpretation: A paradigm for interpretive social philosophy and political criticism", Philosophy and Social Criticism 30, nos. 5/6 (2004): 691-720.
} 
on people. In a recent interview, Rosa makes this position explicit, in connection with Max Weber's famous lecture on science as a vocation:

I think I'm totally true to Weber (...) he says is that each of us must "find and obey the demon who holds the strings of his life", and this is what I mean when I say that you have to find your axis of resonance (...) I think Weber had a kind of similar idea, namely, that you cannot tell where you find your resonance, maybe not even where to look for, but this is what gives meaning to your life, and gives the point and purpose. ${ }^{49}$

But the question remains: To what extent can we really speak of an anthropological invariant when it comes to this notion of resonance? How formal it is? In this respect, one finds counterarguments. Rosa himself has written on the (European) romantic roots of this longing as a style-defining influence on our modern conceptions of love and friendship, art and work, education, and politics. This "resonance sensitivity" remains present and operative among us contemporaries. ${ }^{50}$ If Western modernity is out of tune or mute; if Western modernity (and not other types of societies or epochs) has distorted the resonance relations of human beings; if in this particular social formation it has emerged the distinct longing of hope for reestablishing resonance links with nature, art, and society; if it is possible to trace the elective affinities between such longing and typically modern ideals such as the (Herderian) search for authenticity and originality... then, we may argue that in Rosa's normative critical theory - particularly during his second period of development - there lies an unresolved ambiguity between a more universalistic-ahistorical-formal stance, on one hand, and a more contextualsubstantive one, on the other. In a recent article, Alexis Gros spoke in similar terms of a significant change in Rosa's position from a "weak", contextualist and hermeneutic approach to a "stronger" conception of ethical criticism sustained on the notions of resonance/alienation, as opposite forms of world relations, which "makes a moderate claim for universality". 51 This claim for universality would be "moderate" because it never divorces from the (material) conditions and sufferings of real people; or, to put it differently:

\footnotetext{
${ }^{49}$ Darío Montero, “Teorías de la modernidad. Entrevista con Hartmut Rosa”, (Part 2, min: 28’30).

${ }^{50}$ Rosa, Resonanz, 599-614.

${ }^{51}$ Alexis Gros, "Towards a Phenomenological Critical Theory: Hartmut Rosa's Sociology of the Relationship to the World", Foz, São Mateus - ES 2, no. 1 (2019): 21.
} 
because resonance is presented by its author as a formal category in need of concrete content. This new normative stance gives up the more cultural-contextual ideal of autonomy, so inextricably linked to the rise of the Western, modern culture; but it also "involves a distancing from communitarism and a move towards an approach more akin to the one developed by Honneth." ${ }^{\prime 2}$ Although it is not our aim here to examine in detail the connections between Honneth and Rosa's critical programs, the turn from a contextual sociology of the good life towards the more universal sociology of world-relations seems like a plausible reading of the evolution in Rosa's thinking.

One may even be tempted to suggest that Rosa is inadvertently generalizing a culturally specific trait and making it look as a universally recognizable human capacity with a biological basis. Take for example the following statement:

Resonance is an emotional, neuronal and above all an entirely bodily reality. It is the primary form of our relation to the world. All culturally established forms of life then develop from resonance relationships to specific world relations. Reifying, silencing, distancing world relations are the result of social and cultural learning; they are a cultural technology [Kulturtechnik]. Resonance is therefore a central element of the cultural and social existence. ${ }^{53}$

This is of course a fundamental and thorny problem for all social science and social philosophy: How to reconcile certain observable constants with cultural variation? Rosa's critical social theory builds upon a sort of invariant substantialist perspective that stresses anthropological factors, but also on the recognition of cultural relativism that emphasizes the contingent role of Western modernity. The suspicion of covered ethnocentrism is tackled by Rosa himself in the final pages of his book on resonance, in a passage where he acknowledges that his diagnosis was built "on the basis of specifically Western, capitalist world-relations and it is in this respect neither historically nor transculturally universalizable. ${ }^{\circ 4} \mathrm{He}$ then expresses consistently his willingness to open a dialogue with non-European traditions and forms of life, to uncover the multiplicity of the modern and non-modern world. This brief

\footnotetext{
${ }^{52}$ Ibid., 22.

${ }^{53}$ Rosa, Resonanz, 747.

${ }^{54}$ Ibid., 752.
} 
comment, however, does not resolve the difficulties or tensions we have been pointing out: culture only colors the way humans realize their desire or need for resonance. The desire is a such an acultural or ahistorical phenomenon, valid for all times and places. But, is it so, really?

\section{Criticism upon Rosa's "Critical Theory"}

There are legitimate concerns about the status of Rosa's critical theory. To start with, Rosa himself does not identify his theoretical project with the Critical Theory tradition as such, although he accepts to be identified as part of the fourth generation of Critical Theorists, as long as "true" Critical Theory does not imply "to stick to a narrow set of rules or methodological principles", while insisting that he also draws on other intellectual sources such as phenomenology or Charles Taylor's work. ${ }^{55}$ But beyond the author's own statement, the academic community has shown divided opinions on the critical yield of his approach, even though most of them agree on the great potential of social acceleration for cultural and social studies. ${ }^{56}$ To sum them up, they share a question upon the grounds or causes of social acceleration. If acceleration is the result of the expansion and development of capitalism to a local and global scale, then acceleration is just another face of the modern capitalistic project. In this regard the cultural, economic, and technological motors of the acceleration process identified by Rosa are just epiphenomena of capitalism, and then they can be already found into the traditional criticism of modern reason from the standpoint of the Frankfurt School, and of Marx before it. The thesis of acceleration would also be highly debatable in

\footnotetext{
${ }^{55}$ When asked about his status as critical theorist in an interview, Rosa stated: "I never wanted to be a 'true' adherent to a discipline or what one may call a 'school of thought' or something like this. I am actually never concerned about whether a topic I am interested in (...) is sociological, or psychological, or political, or philosophical. I think the strength of critical theory lies precisely in the fact that it tries to overcome disciplinary boundaries of this kind in its analyses (...) I don't care whether a concept or an idea or a research question stems from critical theory, or from poststructuralist traditions, or from communitarian thinkers or postcolonial authors.” Bjørn Schiermer, "Acceleration and Resonance: An Interview with Hartmut Rosa”, Acta Sociólogica 47, no. 4 (2017): 2.

${ }^{56}$ See Eugene Wolters, "Hartmut Rosa's Social Acceleration Reviewed", Critical-Theory.Com, July 8, 2013, accessed September 2019, available at http://www.critical-theory.com/hartmut-rosas-social-accelerationreviewed/; Filip Vostal, "Towards a social theory of acceleration: Time, modernity, critique", Revue européenne des sciences sociales (online) 52, no. 2 (2014): 235-49, accessed December 2019, available at https://journals.openedition.org/ress/2893; also Esteban Torres, "Reseña Social Acceleration. A New Theory of Modernity", Persona y Sociedad 30, no. 2 (2016): 121-30; and Isaac A. Reed, "Hartmut Rosa's project for critical theory", Thesis Eleven 133, no. 1 (2016): 122-29.
} 
its supposed novelty, as other independent intellectual traditions already address this historical process, as we find it in the works of Hans Blumenberg and Reinhart Koselleck. ${ }^{57}$

To these concerns, we would reply as follows. The key point is not whether Rosa's theory of historical acceleration is 'new' - ignoring the links already established by other traditions of thought - but whether it is able to provide a plausible and operationalizable analysis of its current status and inherent consequences on a global scale. And we do consider that the merit of Rosa's theory of acceleration lies precisely in providing such an analytical overview, thus offering a renovated understanding of the latest stage of global history. By understanding the whole Western project of capitalist modernity as a transformation of temporal structures, we also gain invigorated ways and possibilities for criticism of the material basis of society. If the earlier analyses of Marx, the Frankfurt School, and the tradition of conceptual history are true, then the theory of acceleration represents their continuity and deepening.

On the other hand, there are some concerns about the status of acceleration as a global condition regarding modernity. Arguably, acceleration does not have the same impact in the global South, for instance. Not every place undergoes a process of acceleration with identical intensity; there are differences not only between different places and regions in the world, but within the same society there can exist several paces of social life. One way of responding to this criticism would be to say that the theory of acceleration does not suggest that there is a high-speed social process at every time and everywhere, but rather that, underlying modernity, there is an increased rate of changes and, subsequently, a faster pace of historical development. Indeed, Rosa is aware of this: the conditions for a historical acceleration are latent within Modernity despite of the fact that they are realized. This means that capitalist modernity would be a project with a temporal structure that promotes constant changes without implying transformations at every moment and everywhere - as well as fast social process. Modernity reproduces itself under specific conditions of increasing self-mutations without revolutionary ruptures. Therefore, acceleration does not mean "deep transformations" everywhere at the same time, or a lifestyles always in haste: the historical

\footnotetext{
${ }^{57}$ Hans Blumenberg, "Verspätung der Aufklärung und Beschleunigung ihres Verfahrens" and "Exkurs: Beschleunigung als Heilserwartungsrest", in Lebenszeit und Weltzeit; Reinhart Koselleck, "Gibt es eine Beschleunigung der Geschichte? Zeitverkürzung und Beschleunigung", in Zeitschichten: Studien zur Historik (Frankfurt: Suhrkamp, 2000), and "Neuzeit'. Zur Semantik moderner Bewegungsbegriffe", in Vergangene Zukunft. Zur Semantik geschichtlicher Zeiten (Frankfurt: Suhrkamp, 2000).
} 
conditions for acceleration hold even if a rural region of Bolivia or Norway are not accelerated as such.

In recent years, Rosa has critically examined his own notion of acceleration alongside other scholars. ${ }^{58}$ It must be hold in mind that the thesis of acceleration does not imply a claim for deceleration as the solution. The critique of acceleration is not that acceleration is "bad" and slowness "good". ${ }^{59} \mathrm{He}$ simply aims at criticizing late capitalist conditions through an examination of its basic temporal structure.

Finally, a couple of words on Rosa's resonance theory. Although it falls outside the scope of this article to ponder all existing criticisms, one may well imagine potential concerns regarding the confidence which the resonance perspective puts in a humanistic approach. With a strong emphasis in (human) actors and their resonance, How does Rosa's dialogue with contemporary social theory traditions - those that criticize anthropocentric bias such as the Actor Network Theory, Systems Theory or Poststructuralism? Moreover, we have already pointed out the tensions between universalism and particularism, between anthropological-biological claims on the one hand, and historical-cultural contextualization on the other. Simon Susen has recently written an exhaustive, balanced evaluation of Rosa's approach. In our view, the strongest and most plausible criticisms put forward by Susen could be summed up as follows: First, "[ $\mathrm{t}$ ]he contention that it [resonance] can serve as the yardstick for social critique (...) is, at best, problematic or, at worst, untenable", considering that communication, recognition, production, or artistic expression "are no less central to the construction of emancipatory life forms than resonance." ${ }^{60}$ Second, it is the paradox that, despite Rosa's avoidance of essentialist definitions of human beings, he presupposes a human nature, something like an anthropological invariant: the resonance-seeking orientation. And

\footnotetext{
${ }^{58}$ Klaus Dörre, Stephan Lessenich, and Hartmut Rosa, Sociology, Capitalism, Critique (London: Verso, 2015); "Appropriation, Activation and Acceleration: The Escalatory Logics of Capitalist Modernity and the Crises of Dynamic Stabilization", Theory, Culture \& Society 34, no. 1 (2016): 53-73.

59 'Speed is only 'bad' when it leads to alienation, that is, to the loss of our capacity to truly 'appropriate' the world. It somehow scratches in my ears when I say the word 'appropriation'. I would use the German word anverwandeln* - rather than aneignen** - if I could. Then, anverwandeln entails self-transformation while aneignen is merely instrumental (...) I realized that we need to move beyond the simple dichotomy of bad speed versus good slowness, altogether. I reframed the problem as alienation caused by the mode of dynamic stabilization and started to argue that what we are after, positively, when criticizing acceleration is not slowness". Schiermer, "Acceleration and Resonance", 6.

* To transform, to turn into something else, like mutate assimilating. [Authors' note.]

** To appropriate something [Authors' note].

${ }^{60}$ Simon Susen, "The Resonance of Resonance: Critical Theory as a Sociology of World-Relations?", International Journal of Politics, Culture, and Society (online) (2019), 1-36.
} 
third, it is not clear what aspects of resonance are universalizable and which ones are not: what is common to all societies and all individuals and what is only relevant and real for some.

\section{Final Remarks}

The work of Hartmut Rosa tends to be associated with names such as Rainer Forst, Rahel Jaeggi, Martin Saar or Robin Celikates, as the last wave of Critical Theory intellectuals revolving around the Institut für Sozialforschung in Frankfurt. It was not our purpose to discuss to what extent it is possible to make sense of the label 'fourth generation' within this tradition. In any case, one could safely say that Rosa's writings are one of the most influential among these recent attempts at renewing a critical social theory, not only within scholarly circles but also among public spheres. ${ }^{61}$

In the present paper we have tried to show the usefulness of distinguishing between the structuralist or analytic period of Rosa's social acceleration theory and the more strongly normative conception under the shape of a so-called sociology of the good life, or a sociology of world-relations. We have also noted a shift in his positions from a more contextualist approach to a more universal stance. Now, despite these changes, Rosa is never completely one-sided: even within the functionalist phase, he points to cultural causes behind social acceleration; conversely, his normative theory evidently does not ignore structural factors. To be sure, a potential "critical theory of modernity" of Rosa contains both "cultural" and "acultural" readings of the phenomenon, but his concepts and categories are less fruitful for understanding the peculiarities and idiosyncrasies of the existing multiple modernities around the globe than for unpacking the unitary logic that underlies them. ${ }^{62}$

In a certain way, structural and normative elements, universal and particular standpoints, complement each other; on the other hand, there is an important turn that speaks in favor of a rupture or discontinuity in Rosa's thinking. As one may expect, Rosa has tried to "save" his work from these apparent contradictions, for example, by explicitly announcing

\footnotetext{
${ }^{61}$ Ibid.; also Gros, "Towards a Phenomenological Critical Theory".

${ }^{62}$ Hartmut Rosa, "The Universal underneath the Multiple: Social Acceleration as a Key to Understanding Modernity", in Modernity at the Beginning of the 21st Century, V. Schmidt ed. (Newcastle: Cambridge Scholars Publishing, 2007), chapter III.
} 
his wish to combine functionalist and normative forms of social criticism, the latter split into its moral and ethical versions. In his own words:

I will try to show how a Critical Theory of Social Acceleration could integrate these three forms of social criticism, thereby continuing the tradition of the older versions of Critical Theory which always sought to combine a Marx-inspired functional critique of the inherent and insurmountable (class-) contradictions of capitalist society with a moral critique of its fundamental (distributional) injustice and an ethical critique of alienated life (originating with the early Marx) and false needs. ${ }^{63}$

Another strategy pursued by the author to highlight the fundamental unity of his theorization consisted in displaying the inner connection between his work on Charles Taylor and that on acceleration. ${ }^{64}$ But these questions and problems remain open, and add another kind of complexities to Hartmut Rosa's analysis, one of the most relevant and starting-polemical contributions to the social theory of what goes on twentieth-first century.

\footnotetext{
${ }^{63}$ Rosa, Alienation and Acceleration, 68-9.

${ }^{64}$ Rosa, Weltbeziehung, Chapter 10, 374-413.
} 


\section{Referencias bibliográficas}

Adorno, Theodor W. and Max Horkheimer. Dialectic of Enlightenment. Palo Alto: Stanford University Press, 2002.

Blumenberg, Hans. Lebenszeit und Weltzeit. Frankfurt: Suhrkamp, 1986.

Dörre, Klaus, Stephan Lessenich and Hartmut Rosa. "Appropriation, Activation and Acceleration: The Escalatory Logics of Capitalist Modernity and the Crises of Dynamic Stabilization". Theory, Culture \& Society 34, no. 1 (2017): 53-73.

. Sociology, Capitalism, Critique. London: Verso, 2015.

Gros, Alexis. “Towards a Phenomenological Critical Theory: Hartmut Rosa’s Sociology of the Relationship to the World". Foz, São Mateus - ES 2, no. 1 (2019).

Harvey, David. The Condition of Postmodernity: An Enquiry into the Origins of Cultural Change. Cambridge UK: Blackwell, 1990.

Honneth, Axel. The Critique of Power. Reflective Stages in a Critical Social Theory. K. Baynes translator. Cambridge MA: The MIT Press. 1991.

Jaeggi, Rahel. Entfremdung. Zur Aktualität eines Sozialphilosophischen Problems. Frankfurt: Campus, 2005.

Koselleck, Reinhart. Vergangene Zukunft. Zur Semantik geschichtlicher Zeiten. Frankfurt: Suhrkamp, 2000. Futures Past. On the semantics of Historical Times. Keith Tribe translator. New York: Columbia University Press, 2004.

"Gibt es eine Beschleunigung der Geschichte? Zeitverkürzung und

Beschleunigung”. In Zeitschichten: Studien zur Historik. Frankfurt: Suhrkamp. 2000. “'Neuzeit'. Zur Semantik moderner Bewegungsbegriffe”. In Vergangene Zukunft.

Zur Semantik geschichtlicher Zeiten. Frankfurt: Suhrkamp. 2000.

Löwith, Karl. "Weber's Interpretations of the Bourgeois-Capitalistic World in Terms of the Guiding Principle of 'Rationalization'”. In Max Weber. Dennis Wrong editor, 101-22. Englewood Cliffs NJ: Prentice-Hall, 1970).

Lübbe, Hermann. "The Contraction of the Present". In High-speed society: social acceleration, power, and modernity. Hartmut Rosa and William Scheuerman editors, 159-78. University Park: Pennsylvania State University, 2009. 
Marcuse, Herbert. One-Dimensional Man. London: Routledge, 2006.

Montero, Darío. "La modernidad acelerada y sus desafíos. Una conversación con Hartmut Rosa". Revista de Humanidades 41 (2020): 281-307.

. "Theories of Modernity. Interview with Hartmut Rosa", record, part 2, min: 10'55.

Centro para las Humanidades, Universidad Diego Portales, Santiago, Chile, 2018, accessed August 2019, available at https:/www.centroparalashumanidadesudp.cl/1393$2 /$.

"Aceleración, alienación y resonancia. Entrevista con Hartmut Rosa". In Investigación y teoría crítica para la sociedad actual, Mauro Basaure and Darío Montero editors. Barcelona: Editorial Anthropos, 2018.

Reed, Isaac A. "Hartmut Rosa's project for critical theory”. Thesis Eleven 133, no. 1 (2016): 122-129.

Rosa, Hartmut. Resonance: a Sociology of Our Relationship to the World. James C. Wagner translator. Cambridge UK: Polity Press, 2019.

Resonancia: Una sociología de la relación con el mundo. Alexis Gros translator. Buenos Aires: Katz ediciones, 2019.

. Resonanz eine Soziologie der Weltbeziehung. Berlin: Suhrkamp, 2016.

Alienación y aceleración: Hacia una teoría crítica de la temporalidad en la modernidad tardía. CEIICH translators. Buenos Aires: Katz ediciones, 2016.

Social Acceleration. A New Theory of Modernity. Jonathan Trejo-Mathys translator. New York: Columbia University Press, 2013.

Weltbeziehungen im Zeitalter der Beschleunigung. Umrisse einer neuen Gesellschaftskritik. Frankfurt: Suhrkamp, 2012.

"Is There Anybody out There? Stumme und resonante Weltbeziehungen - Charles Taylors monomanischer Analysefokus”. In Unerfüllte Moderne? Neue Perspektiven auf das Werk von Charles Taylor. Michael Kühnlein and Matthias Lutz-Bachmann editors, 15-43. Berlin: Suhrkamp, 2011.

"Aceleración social: consecuencias éticas y políticas de una sociedad de alta velocidad desincronizada", Fernando Campos and María I. Vila translators. Persona y Sociedad XXV, no. 1 (2011): 9-19. 
Alienation and Acceleration. Towards a Critical Theory of Late-Modern

Temporality. Malmö: NSU Press, 2010.

. "Jedes Ding hat keine Zeit? Flexible Menschen in rasenden Verhältnissen”. In

Zeitgewinn und Selbstverlust: Folgen und Grenzen der Beschleunigung. Vera King and

Benigna Gerisch editors, 21-39. Frankfurt: Campus, 2009.

. "Kapitalismus als Dynamisierungsspirale - Soziologie als Gesellschaftskritik". In

Soziologie - Kapitalismus - Kritik. Klaus Dörre, Stephan Lessenich, and Hartmut Rosa editors. Frankfurt: Suhrkamp, 2009.

- "The Universal underneath the Multiple: Social Acceleration as a Key to

Understanding Modernity". In Modernity at the Beginning of the 21st Century. Volker

H. Schmidt editor. Newcastle: Cambridge Scholars Publishing, 2007.

. Beschleunigung. Die Veränderung der Zeitstrukturen in der Moderne. Frankfurt:

Suhrkamp, 2005.

. "The Speed of Global Flows and the Pace of Democratic Politics". New Political

Science 27 (2005): 445-459.

. "Four levels of self-interpretation: A paradigm for interpretive social philosophy and

political criticism". Philosophy and Social Criticism 30, no. 5/6 (2004): 691-720.

. "Social Acceleration: Ethical and Political Consequences of a Desynchronized

High-Speed Society". Constellations 10, no. 1 (2003): 3-33.

. "Bewegung und Beharrung. Überlegungen $\mathrm{zu}$ einer sozialen Theorie der

Beschleunigung”. Leviathan 27, no. 3 (1999): 386-414.

. Aceleración. La transformación de las estructuras temporales en la modernidad.

Felipe Torres translator. Mexico City: Herder, forthcoming.

Schiermer, Bjørn. “Acceleration and Resonance: An Interview with Hartmut Rosa”. Acta

Sociólogica 47, no. 4 (2017).

Susen, Simon. "The Resonance of Resonance: Critical Theory as a Sociology of World-

Relations?". International Journal of Politics, Culture, and Society (online) (2019): 136.

Taylor, Charles. “Two Theories of Modernity”. Hastings Center Report 25 (1995): 24-33.

Torres, Esteban. "Reseña Social Acceleration. A New Theory of Modernity". Persona y Sociedad 30, no. 2 (2016): 121-30. 
Torres, Felipe. “Tiempo Histórico. Una promesa de aceleración”. Isegoría 59 (2018): 553571.

. "A secular Acceleration. Theological foundations of the sociological concept 'Social Acceleration"”. Time \& Society 25, no. 3 (2016): 429-49.

Virilio, Paul. Rasender Stillstand. Essay. Munich: Hanser, 1992.

Speed and Politics: An Essay on Dromology. New York: Semiotext(e), 1986.

Vostal, Filip. "Towards a social theory of acceleration: Time, modernity, critique". Revue européenne des sciences sociales (online) 52, no. 2 (2014): 235-249. Accessed December 2019, available at https://journals.openedition.org/ress/2893.

Weber, Max. Wirtschaft und Gesellschaft. Tubingen: Mohr, [1921] 1976.

Economy and Society. Ephraim Fischoff et al. translators. New York: Bedminister, 1968.

Wolters, Eugene "Hartmut Rosa's Social Acceleration Reviewed". Critical-Theory.Com, July 8, 2013. Accessed September 2019, available at http://www.criticaltheory.com/hartmut-rosas-social-acceleration-reviewed/.

\section{Sobre los autores}

Darío Montero. Assistant Professor of Sociology at the Universidad de Chile (Santiago, Chile). Doctor of Sociology by the University of Jena, Germany; Master of Public Policy by the Willy Brandt School of Public Policy at the University of Erfurt; and sociologist with a Minor in Philosophy by the Pontificia Universidad Católica de Chile. He teaches political philosophy and sociological theory. Research assistant at the Centre for Social Conflict and Cohesion Studies (COES) from 2014 to 2018. He was guest editor for journals Persona y Sociedad and Arte y Sociedad. His publications deal with democracy, political cultures, national identities. Currently, he is working on a large study on the rise of modern society. He is co-author with Mauro Basaure of Investigación y teoría critica para la sociedad actual (Barcelona: Editorial Anthropos 2018). E-mail: dario.montero@uchile.cl.

Felipe Torres. Doctoral researcher in Social and Cultural Studies at the Max Weber Kolleg of Universität Erfurt (Erfurt, Germany). Master on Contemporary Thought by the 
Universidad Diego Portales, and sociologist with a minor in philosophy by the Universidad Alberto Hurtado, Chile. His research topics focus on social theory, postructuralism, political thought and conceptual history. He was instructor of politics and social theory at the Universidad Diego Portales, Universidad Andrés Bello, and Universidad Adolfo Ibáñez in Chile. Editor of Pléyade (2012-2015). He is currently translating Hartmut Rosa's book Beschleunigung. Die Veränderung der Zeitstrukturen in der Moderne into Spanish that will be published by Herder (forthcoming, 2020), and editing a volume on Reinhart Koselleck in Spanish by Pólvora (forthcoming, 2020). E-mail: felipe.torres@uni-erfurt.de. 